\title{
Effects of trichlorobenzene on natural phytoplankton populations
}

\author{
N.A. ANDRESEN and L. SICKO-GOAD* \\ Center for Great Lakes and Aquatic Sciences, The University of Michigan, 2200 Bonisteel Blvd., Ann Arbor, \\ MI 48109-2099 USA
}

Received 17 March; accepted 21 July 1993

Natural phytoplankton assemblages from an offshore station in Lake Michigan were exposed to individual isomers of trichlorobenzene (TCB) and incubated in situ for a $24 \mathrm{~h}$ period. One set of exposures was initiated with a lake assemblage collected at $0330 \mathrm{~h}$ from $30 \mathrm{~m}$ and the TCB isomers added at $0400 \mathrm{~h}$. The second exposure experiment was initiated with an assemblage from $30 \mathrm{~m}$ collected at $1530 \mathrm{~h}$ and the TCB isomers added at $1600 \mathrm{~h}$.

Comparisons of the chlorophyll $a$ to neutral lipid ratio and the neutral to polar lipid ratios suggest that 1,2,3-TCB is more toxic than 1,2,4-TCB. Furthermore, more effects were observed when exposures were initiated at $0400 \mathrm{~h}$ when compared with a parallel experiment initiated at $1600 \mathrm{~h}$. These studies with natural assemblages support culture studies of effect as a function of time of exposure.

Keywords: trichlorobenzene; lipid class; phytoplankton; diatoms; chlorinated hydrocarbons; toxicity; algae.

\section{Introduction}

Many of the most persistent toxic substances entering aquatic ecosystems are lipophilic compounds. Our research on cultured diatom species has demonstrated that the timing of the initial exposure to trichlorobenzene (TCB) isomers may affect the outcome of exposure experiments (Sicko-Goad et al. 1989a,b,c,d, Sicko-Goad and Andresen $1993 \mathrm{a}, \mathrm{b})$. That is, more effects are observed when diatom cultures are exposed to TCB in the early part of the day. Subsequent studies of diel lipid composition in cultured species demonstrated that in most of the diatoms examined, there was a periodicity in lipid class composition. Exposure to chlorinated benzenes when the diatoms were going through a transition state from low concentrations of polar lipids and pigments to higher concentrations of these classes resulted in toxicity effects that were observed within 48 h. When exposures were initiated during periods of high concentrations of neutral lipids, effects were observed in many diatoms as late as 4 to 10 days after the initial exposure (Sicko-Goad and Andresen 1993a,b). These observations led us to believe that the timing of the initial exposure, as a consequence of lipid class composition, could ameliorate or amplify exposure effects.

The extrapolation of single-species bioassays and toxicity studies to higher levels of biological organization (i.e. ecosystem or multispecies effects) has been the focus of

*To whom correspondence should be addressed. 
much debate in the literature (e.g. Cairns 1984, Borgmann 1985, Abou-Waly et al. 1991). It has been suggested that natural phytoplankton assemblages may be more sensitive to toxicant exposure for a variety of reasons, including fluctuations in natural light intensity, mixing and stratification into waters of varying nutrient regimes (Ruben et al. 1990). Nyholm (1991) demonstrated that significant toxic effects on phosphate uptake occur at toxicant concentrations that are only slightly inhibitory to growth, suggesting that inhibited phosphate uptake may influence interspecies competition. Similarly, Jenkins and Buikema (1990) demonstrated that simazine exposure differentially impacted phytoplankton and zooplankton species composition and abundance, and they suggested that indirect effects observed as a result of exposure depend on food web structure at the time of exposure and the degree of 'adaptability' of the particular organisms in the food web.

We have obtained positive and reproducible results in cultures suggesting that lipid class composition at the time of exposure to lipophilic chlorinated compounds is predictive of response. Since higher sorption of chlorinated solvents to algae has been related to lipid content and/or composition (Grimes and Morrison 1975, Smets and Rittmann 1990), we conducted exposure experiments with TCBs on natural phytoplankton assemblages from an offshore station in Lake Michigan. Exposure experiments were conducted using 1,2,3- and 1,2,4- TCB in July 1991. TCB is one of the priority pollutants listed by the USEPA.

\section{Materials and methods}

Experiments were conducted on 11-12 July 1991 at a station in Lake Michigan ca. 32 $\mathrm{km}$ offshore from Grand Haven, Michigan, at the $100 \mathrm{~m}$ contour. At $0200 \mathrm{~h}$, profiles of the Lake were taken with a Seabird CTD (conductivity, temperature, depth) to determine water temperature, depth, conductivity, $\mathrm{pH}$, dissolved oxygen, percent of light transmission, and fluorescence. Water samples from 10,20 , and $30 \mathrm{~m}$ were obtained with Niskin bottles every $4 \mathrm{~h}$ for the next $40 \mathrm{~h}$. Water samples were prescreened with a number $10(153 \mu \mathrm{m})$ plankton net to remove large zooplankton. They were then filtered onto Gelman glass fibre filters for diel studies of lipid content and onto membrane filters for phytoplankton composition and abundance.

Exposure experiments were conducted on assemblages taken at two different times $(0300$ and $1530 \mathrm{~h}$ ) from a depth of $30 \mathrm{~m}$, which corresponded to the fluorescent maximum in the lake. Water was obtained with a 301 Niskin. This water was also prescreened through a number 10 net to remove large zooplankton and the water was split into 61 aliquots and placed in four separate cleaned and sterile 81 polypropylene bottles. 1,2,3TCB was added to one bottle to give a final concentration of $0.3 \mathrm{ppm}$, while $1,2,4-\mathrm{TCB}$ was added to the second bottle at the same concentration. Bottles exposed to TCB were paired with bottles containing no chlorobenzenes. Controls for each exposure were established to monitor any differences in incubation environment. All bottles were sealed, secured with line, and weighted. The paired bottles were placed on a line secured to the research vessel and incubated in Lake Michigan for a period of $24 \mathrm{~h}$, at a depth of approximately $3 \mathrm{~m}$. Incubations were initiated at 0400 and $1600 \mathrm{~h}$ resulting in two separate experiments. Eventual analysis demonstrated enough similarity in the controls at each incubation time that the resulting data was pooled.

The samples taken for lipid class composition were taken in duplicate, filtered onto 
prewashed and preweighed Gelman A/E glass fibre filters. One duplicate was dried in a vacuum oven at $60^{\circ} \mathrm{C}$ for $24 \mathrm{~h}$, then reweighed to determine dry weight. The duplicate for lipid analysis was frozen immediately. Upon return to the lab, the frozen filters were placed in pre-extracted thimbles and extracted with chloroform/methanol $(2: 1 \mathrm{v} / \mathrm{v})$ for $12 \mathrm{~h}$ in a micro-Soxhlet (Orcutt and Patterson 1975). The extract was concentrated, redissolved in chloroform and washed with water in a separatory funnel, dried under a nitrogen stream in a pre-weighed Teflon-lined screw cap amber vial and weighed for total gravimetric lipid (TEL). Samples were flushed with nitrogen and frozen for lipid class analyses.

Samples were unfrozen and redissolved in methylene chloride to concentrations of 20-50 $\mu \mathrm{g}$ lipid in spotting volumes of 10-20 $\mu \mathrm{l}$ for lipid class analysis. The extracts were spotted with Hamilton syringes onto cleaned and blank-scanned silica coated Chromarods (type SIII). Rods were held in a frame and developed, then scanned in an Iatroscan Mark IV Thin Layer Chromatography-Flame Ionization Detection (TLC-FID) (RSS Inc., Costa Mesa, CA) system using the development scheme of Parrish (1986). The development was three staged:

(1) The rods were developed in $50 \mathrm{ml}$ solution of hexane, diethyl ether, and formic acid (98:2:0.5) for $30 \mathrm{~min}$, conditioned for $5 \mathrm{~min}$, followed by re-development in the same solvent system for $25 \mathrm{~min}$. Rods were then partially scanned for hydrocarbons, wax/sterol esters, and ketones. Wax and sterol esters co-elute in this system while $\beta$ carotene migrates with hydrocarbons.

(2) Rods were then reconditioned and developed in $50 \mathrm{ml}$ of a solution of hexane, diethyl ether and formic acid (80:20:0.1) for $50 \mathrm{~min}$. Rods were scanned for triacylglycerols, free fatty acids, alcohols and sterols. Since triacylglycerols and free fatty acids are difficult to separate if the load on the chromarod is greater than $10 \mu \mathrm{g}$, the area of the split peak was combined into one class labelled TG/FFA. Diacylglycerols have an Rf value near that of sterols. No diacylglycerol peaks were observed in any samples.

(3) The third development consisted of two 15-min developments in $100 \%$ acetone followed by two 10 -min developments in dichloromethane, methanol, and water $(5: 4: 1)$. Rods were then scanned for chlorophyll $a(\mathrm{Chl} a)$, acetone-mobile polar lipids (AMPL), and a class containing phospholipids and acetone-immobile polar lipids. During the last scan, a Flame Thermionic Ionization (FTID) detector was also used for the additional detection of $\mathrm{N}$ in $\mathrm{Chl} a$ and phospholipids. The AMPL fraction may contain monoglycerides and glycolipids. Chlorophyll data from the TLC-FTID method were compared with standard fluorometric measurements from two experiments. The data were in agreement within one standard error of the TLC-FTID method.

Quantitative determinations of lipid class composition are based on dose-response calibration equations generated by analysis of a wide range of concentrations of standards for each lipid class (Parrish and Ackman 1985). Standards were obtained from Sigma at a purity of $>99 \%$ for lipid class composition studies. All lipid class composition determinations were run in duplicate. Thus, data reported are averages of four replicates for each time determination.

For comparative purposes, all neutral and all polar lipid classes were summed and ratios were calculated for each replicate. Data presented in the following figures represent the net change in the sums of these categories for all replicates. Since control bottles were replicated for the 0400 and $1600 \mathrm{~h}$ experiments, control data were pooled 
and are reported as the mean \pm 1 standard error. Error bars are not presented for experimental bottles since all replicate analyses were from individual exposure flasks.

Whole mounts of phytoplankton were made from $100 \mathrm{ml}$ sample aliquots, fixed with glutaraldehyde and paraformaldehyde (method b, Sicko-Goad et al. 1984) and refrigerated. Slides were prepared by filtering $50 \mathrm{ml}$ of sample onto $0.45 \mu \mathrm{m}$ membrane filters. Filters were then dehydrated with washes of 50 and $95 \%$ ethanol. The moist filter was placed on a slide and the filters were cleared with clove oil. Phytoplankton composition and abundance studies were performed with a Leitz Ortholux microscope with bright field optics.

\section{Results}

\section{Phytoplankton Species Composition}

The assemblage species composition at $0400 \mathrm{~h}$ was a typical offshore, Lake Michigan summer stratification flora dominated by Asterionella formosa Hass. with subdominants of Fragilaria crotonensis Kitton and several Cyclotella species. Diatoms accounted for ca. $90-95 \%$ of all cells. Rhodomonas minuta var nannoplanctica Skuja and species of Cryptomonas were the next most dominant taxa, followed by minor occurrences of Cyanophyta, Chlorophyta, and Chrysophyta.

At $1600 \mathrm{~h}$, diatoms remained as the dominant taxa. A larger number of Cyclotella taxa appeared in the samples taken at this time suggesting a vertical migration of populations. We observed a slight shift in the depth of the fluorescent peak as the day progressed, providing additional evidence for vertical migration (Fig. 1).

Exposure to TCB resulted in reduced numbers of cells (in total cells $\mathrm{ml}^{-1}$ ) for all treatments (Fig. 2). Lower total cell counts appeared to result from reductions in abundance in the most common taxa across the samples. The greatest reduction in cell numbers was observed with $1,2,4,-\mathrm{TCB}$ exposure at $1600 \mathrm{~h}$.

\section{Diel Periodicities in Natural Phytoplankton Assemblages}

Profiles of temperature, $\mathrm{pH}$, and fluorescence at the sampling station are presented in Fig. 1. The fluorescence peak was located between 20 and $30 \mathrm{~m}$, although there was evidence of vertical movement of the maximum during the $24 \mathrm{~h}$ period. Data characterizing the phytoplankton assemblage over a $24 \mathrm{~h}$ period are presented in Fig 3-6. Dry weight was variable in both the 20 and $30 \mathrm{~m}$ samples, with a periodicity of approximately $12 \mathrm{~h}$ (Fig. 3), and with dry weight higher in the night-time hours. Dry weight in the 10 $\mathrm{m}$ sample was much less variable. The physiological parameters of the natural phytoplankton assemblages varied with time of day (Figs 4-6). Total extractable lipid (TEL) varied both with depth and time. The $10 \mathrm{~m}$ samples displayed the least variability throughout the day (Fig. 4). In general, TEL was usually highest in the daylight hours. Diel chlorophyll content is presented in Fig. 5. Chlorophyll (as a percentage of the TEL) was lowest at $0400 \mathrm{~h}$. However, there was a substantial increase in chlorophyll between 0400 and $0800 \mathrm{~h}$.

Diel data for neutral/polar lipid ratios and chlorophyll a/neutral lipid ratios are presented in Fig. 6. The two assemblages selected for study $(0400 \mathrm{~h}$ and $1600 \mathrm{~h}$ from 30 $\mathrm{m}$, the fluorescence maximum) can be characterized as follows:

$0400 \mathrm{~h}$ - Low TEL, low chlorophyll, high neutral/polar lipid ratio and low chlorophyll a/neutral lipid ratio. 

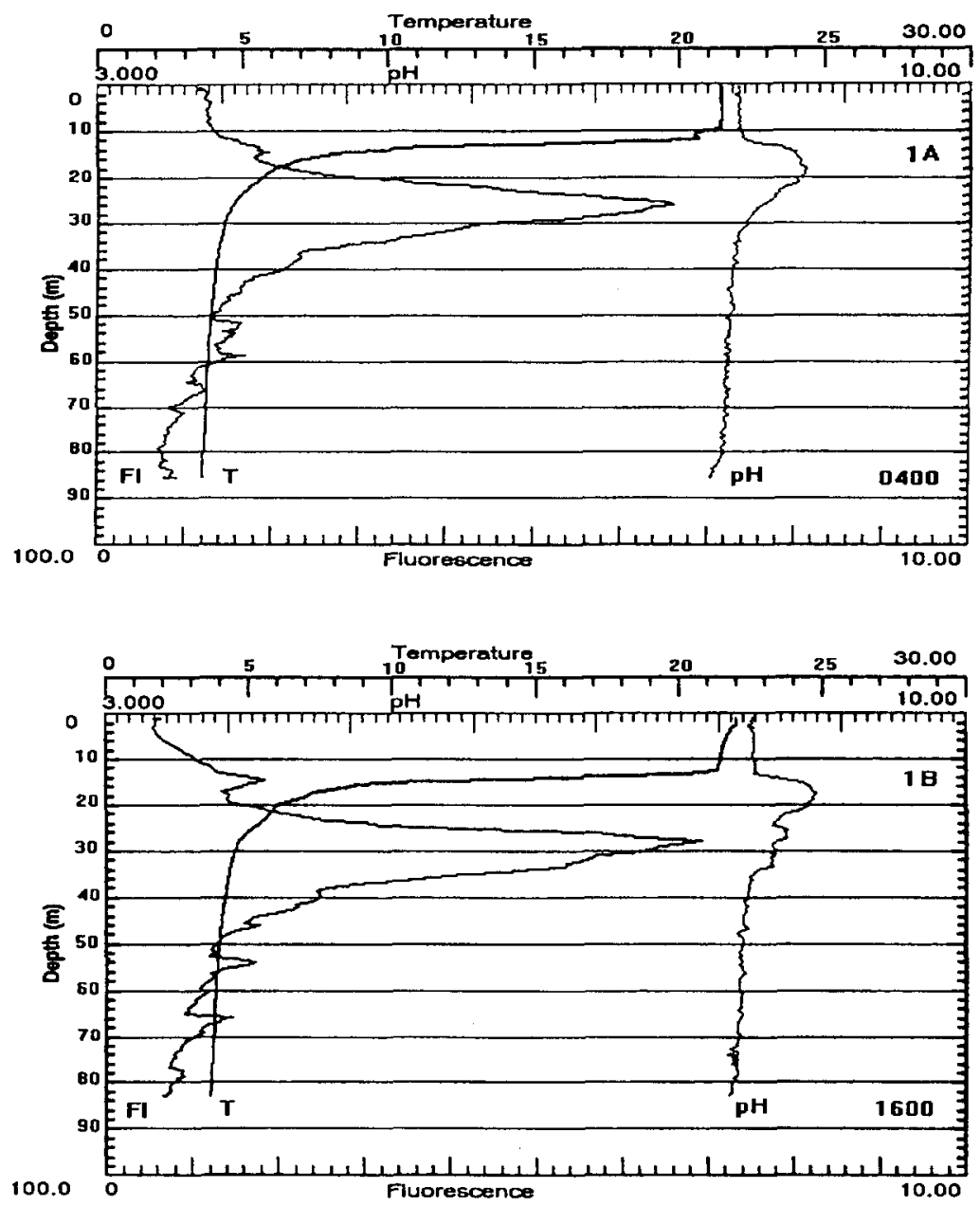

Fig. 1. A. Seabird CTD determined profile of temperature (T), $\mathrm{pH}$, fluorescence (FL) of the Lake Michigan station on 11 July 1991 at 0400 h. B. Seabird CTD determined profile of the same parameters of the Lake Michigan station on 11 July 1991 at $1600 \mathrm{~h}$.

$1600 \mathrm{~h}$ - High TEL, high chlorophyll, neutral to polar lipid ratio similar to that of the $0400 \mathrm{~h}$ assemblage, and a high chlorophyll a/neutral lipid ratio.

\section{Trichlorobenzene Exposures}

Dry Weight and TEL

The $24 \mathrm{~h}$ exposure to 1,2,4-TCB (Fig. 7) resulted in no significant change in dry weight. There appeared to be an increase in TEL with exposure to this isomer in the experiment initiated at $0400 \mathrm{~h}$. Figure 8 depicts reductions in dry weights for both the 0400 and $1600 \mathrm{~h}$ exposure experiments with 1,2,3-TCB. However, with 1,2,3-TCB exposure, the increase in TEL was observed in the $1600 \mathrm{~h}$ experiment. 


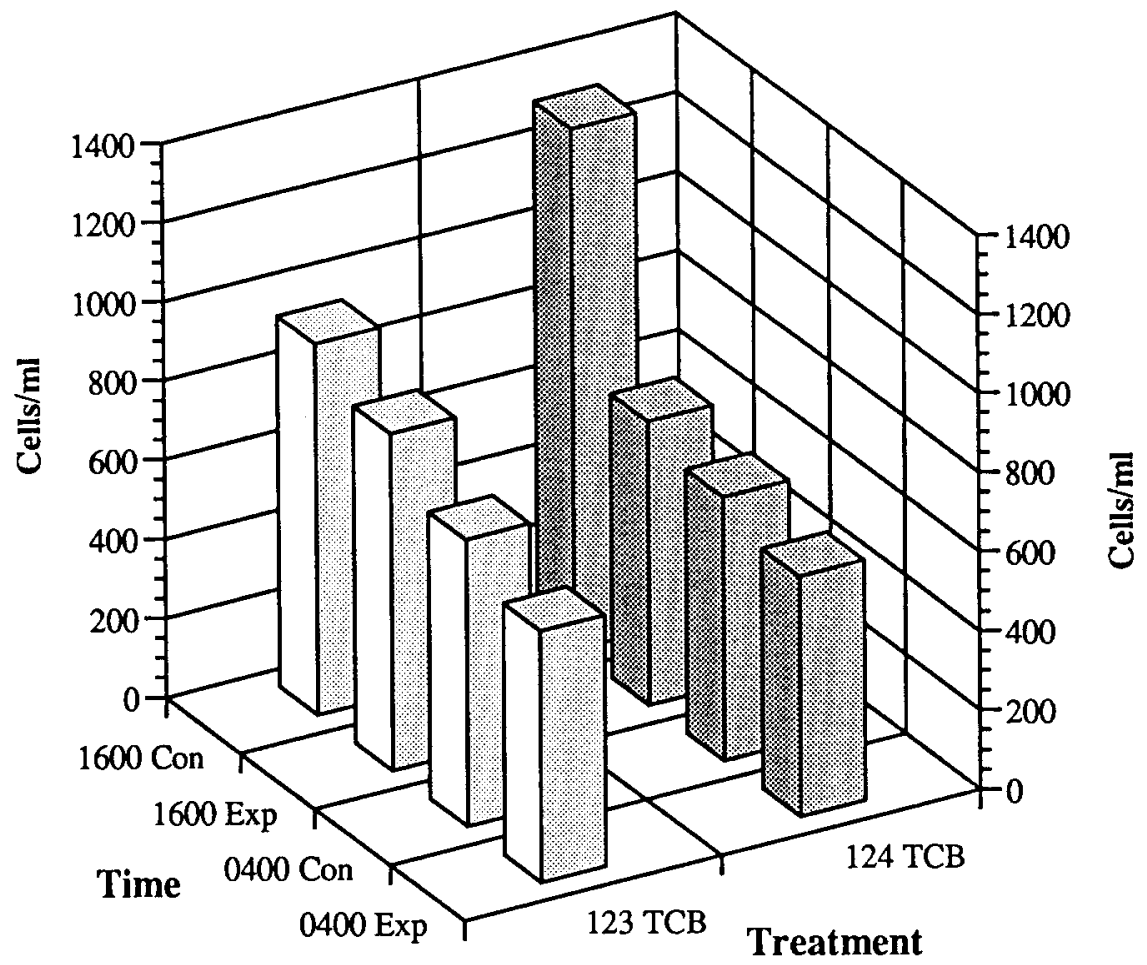

Fig. 2. Change in total cells $\mathrm{ml}^{-1}$ after exposure to 1,2,3-trichlorobenzene and 1,2,4trichlorobenzene. $\mathrm{CON}=$ control; $\mathrm{EXP}=$ exposed.

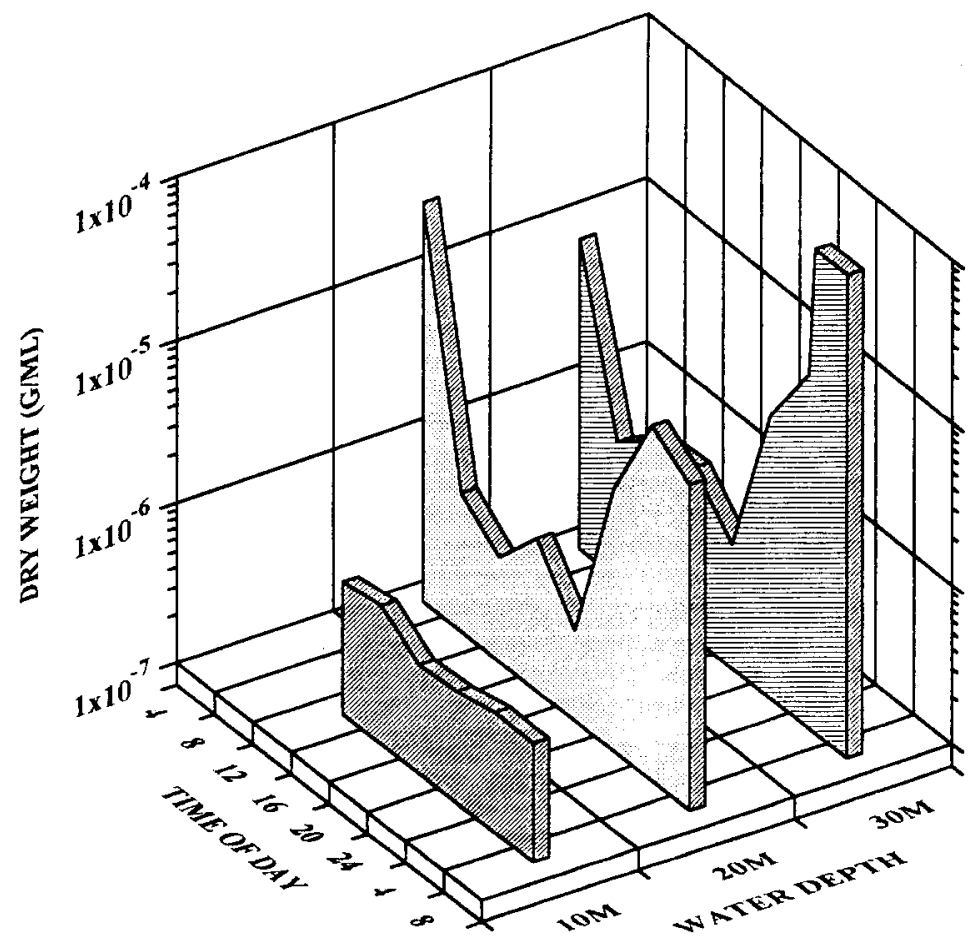

Fig. 3. Diel dry weight distribution of phytoplankton assemblage at depths of 10,20 , and $30 \mathrm{~m}$. 


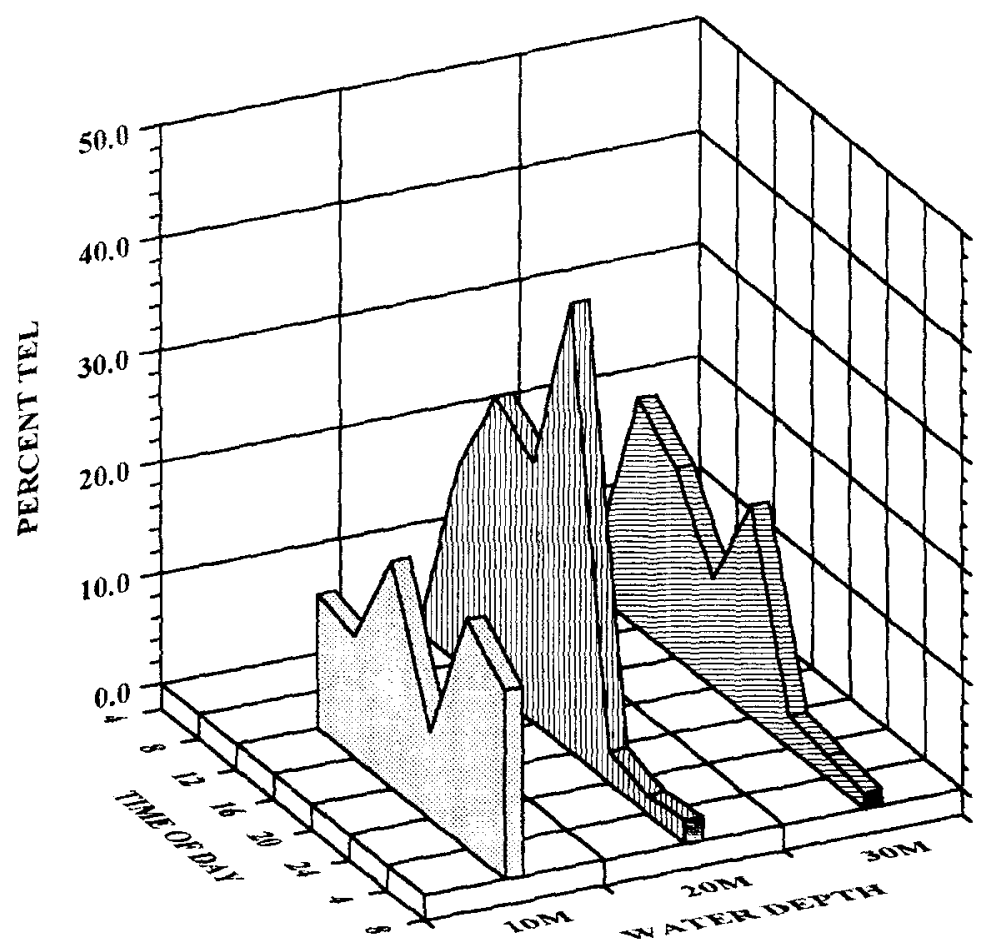

Fig. 4. Diel total extractable lipid (TEL) of phytoplankton assemblage at depths of 10 , 20 , and $30 \mathrm{~m}$.

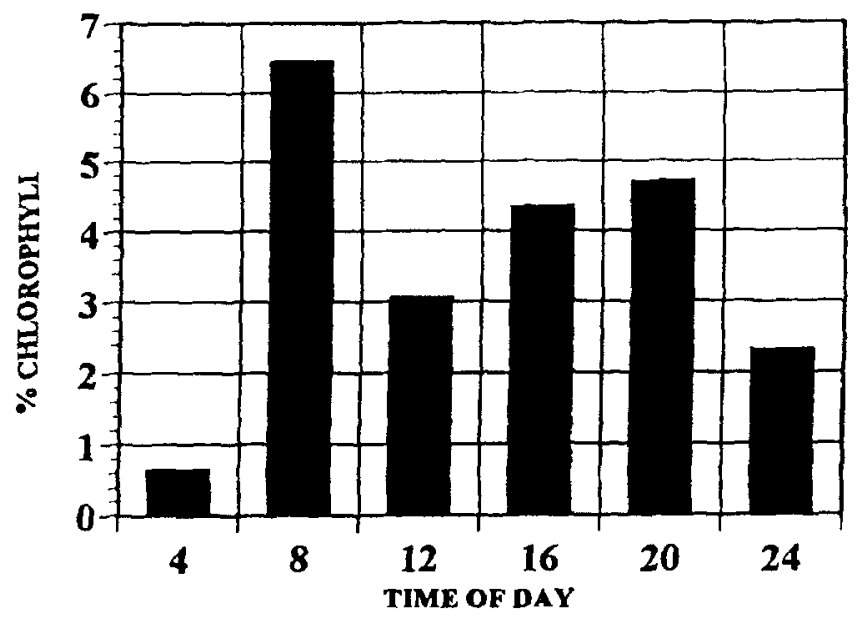

Fig. 5. Diel chlorophyll $a$ patterns of the phytoplankton assemblage at $30 \mathrm{~m}$. Chlorophyll $a$ reported as percentage of TEL. 


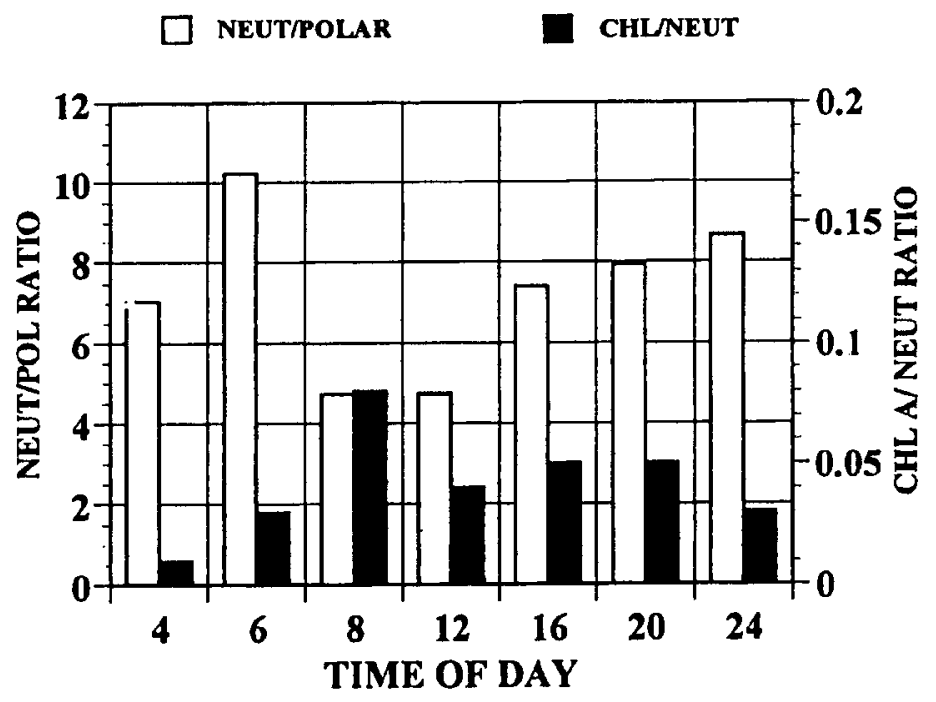

Fig. 6. Diel neutral to polar lipid ratio and chlorophyll $a$ to neutral lipid ratio of the assemblage at $30 \mathrm{~m} . \mathrm{CHL}=$ Chlorophyll $a$; NEUT $=$ neutral; $\mathrm{POL}=$ polar.

DRY WT

$\square$ TEL

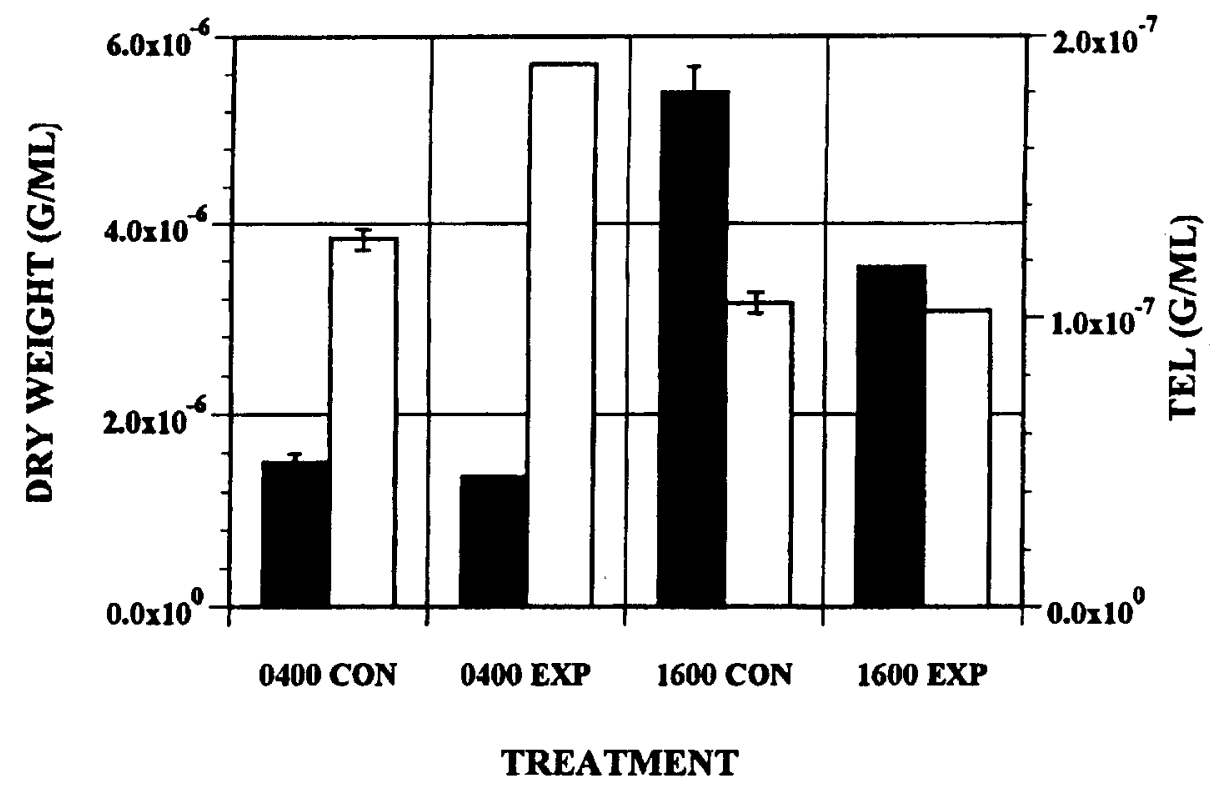

Fig. 7. Comparison of dry weight and TEL in control bottles and after exposure to $1,2,4$ trichlorobenzene. $\mathrm{CON}=$ control; $\mathrm{EXP}=$ exposed; error bars represent one SE. 


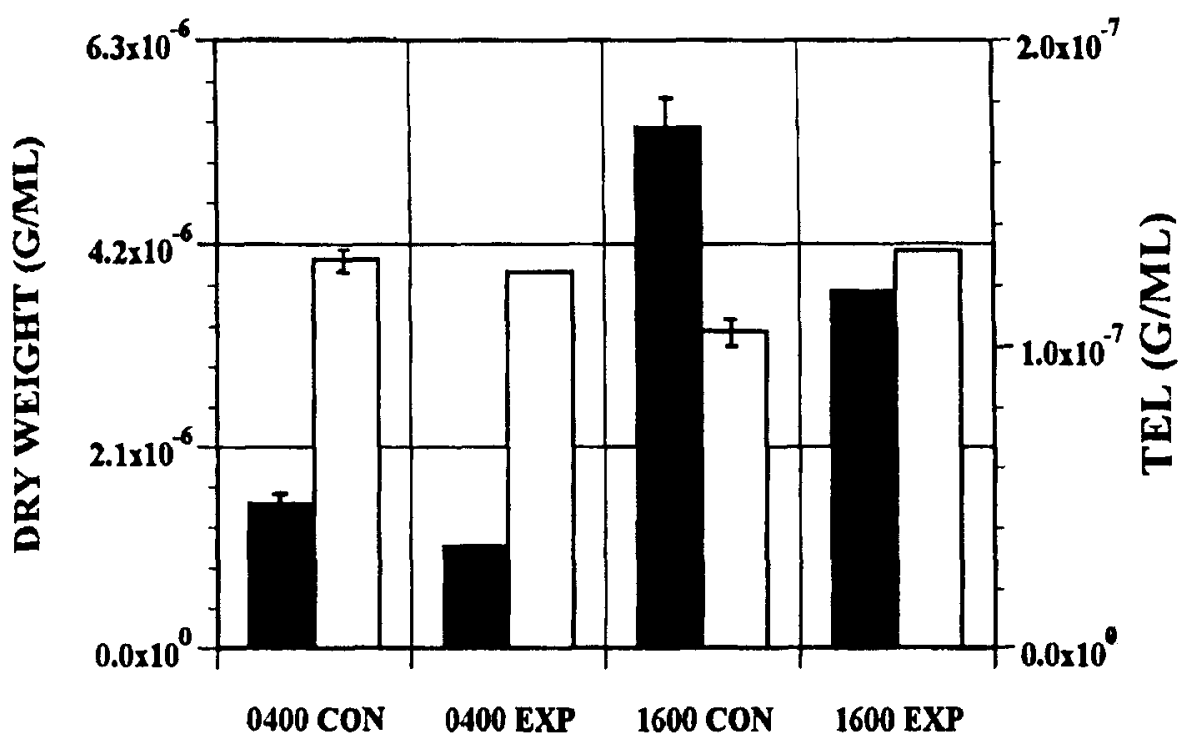

TREATMENT

Fig. 8. Comparison of dry weight and TEL after exposure to 1,2,3-trichlorobenzene. $\mathrm{CON}=$ control; $\mathrm{EXP}=$ exposed; error bars represent one SE.

\section{Lipid ratios}

The neutral/polar lipid ratio increased slightly with the $0400 \mathrm{~h}$ exposure to 1,2,4-TCB and decreased slightly with the $1600 \mathrm{~h}$ exposure (Fig. 9). Both exposures at 0400 and $1600 \mathrm{~h}$ resulted in slight decreases in the chlorophyll $a /$ neutral lipid ratios.

In contrast, exposure to 1,2,3-TCB (Fig. 10) resulted in a large increase in the neutral/ polar lipid ratio and a large decrease in the chlorophyll a/neutral lipid ratio when the exposure was initiated at $0400 \mathrm{~h}$. Similar patterns were observed in the $1600 \mathrm{~h}$ exposure, except the changes were much smaller in magnitude.

Chlorophyll as a percent of TEL

Figures 11-12 demonstrate that, in general, exposure to either isomer, regardless of time, resulted in a decrease in chlorophyll. However, the largest reduction in chlorophyll occurred in the 0400 exposure to $1,2,3-\mathrm{TCB}$.

\section{Discussion}

Results presented here are in agreement with laboratory exposure experiments on cultures of single diatom taxa which demonstrated that diel variations in physiological parameters may lead to the expression of different toxicant effects if exposure to the 


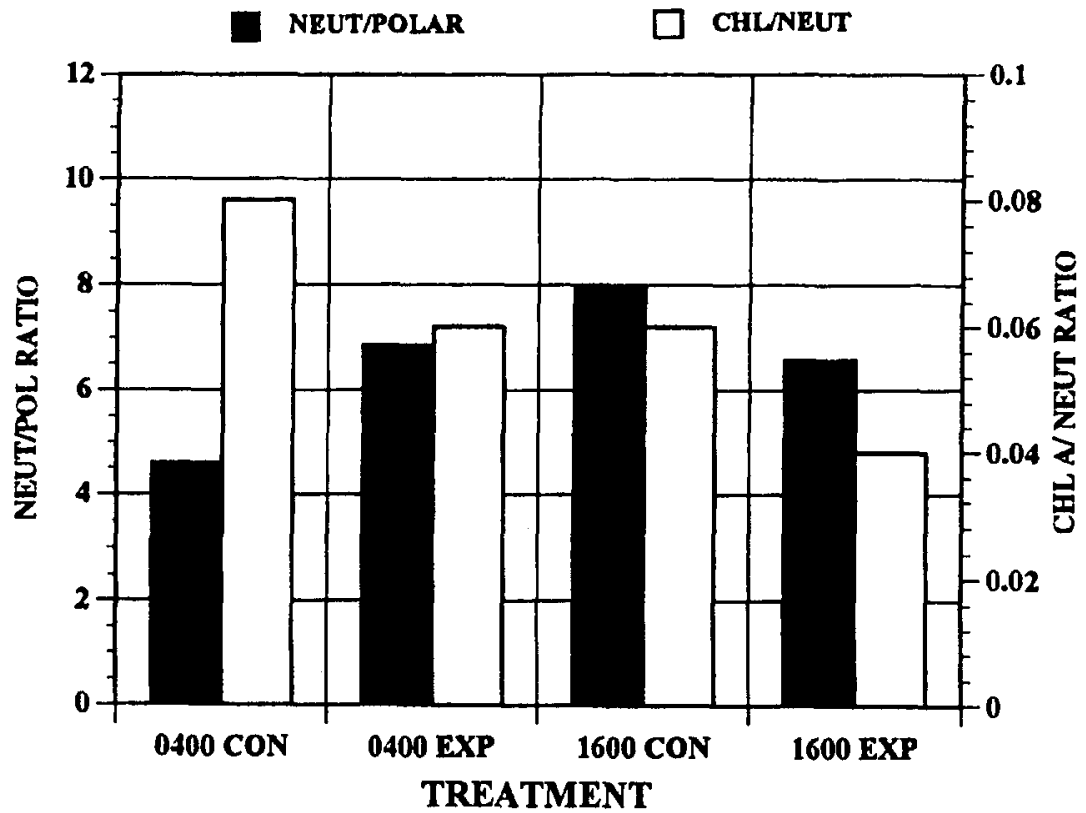

Fig. 9. Change in neutral to polar lipid ratio and chlorophyll $a$ to neutral lipid ratio in control bottles and after exposure to 1,2,4-trichlorobenzene. $\mathrm{CON}=$ control; $\mathrm{EXP}=$ exposed; $\mathrm{NEUT}=$ neutral $; \mathrm{CHL}=$ Chlorophyll $a ; \mathrm{POL}=$ polar.

DEUT/POLAR $\square$ CHLNEUT

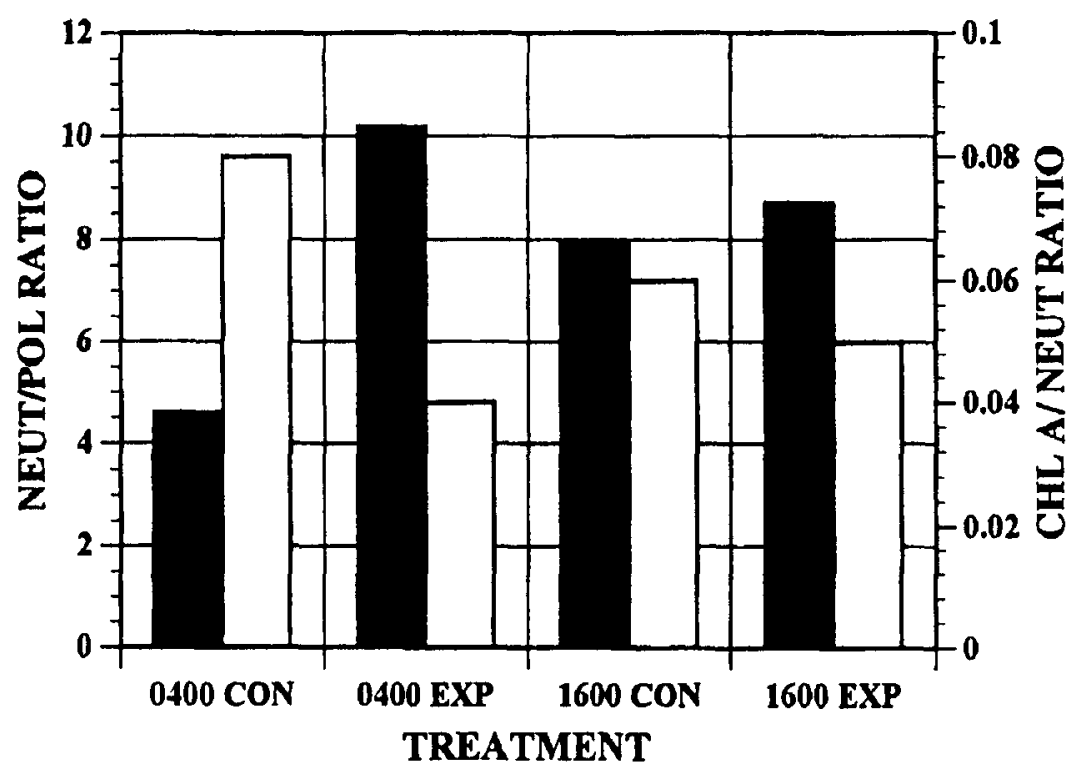

Fig. 10. Change in neutral to polar lipid ratio and chlorophyll $a$ to neutral lipid ratio after exposure to 1,2,3-trichlorobenzene. $\mathrm{CON}=$ control; $\mathrm{EXP}=$ exposed; NEUT $=$ neutral; $\mathrm{CHL}=$ Chlorophyll $a ; \mathrm{POL}=$ polar. 


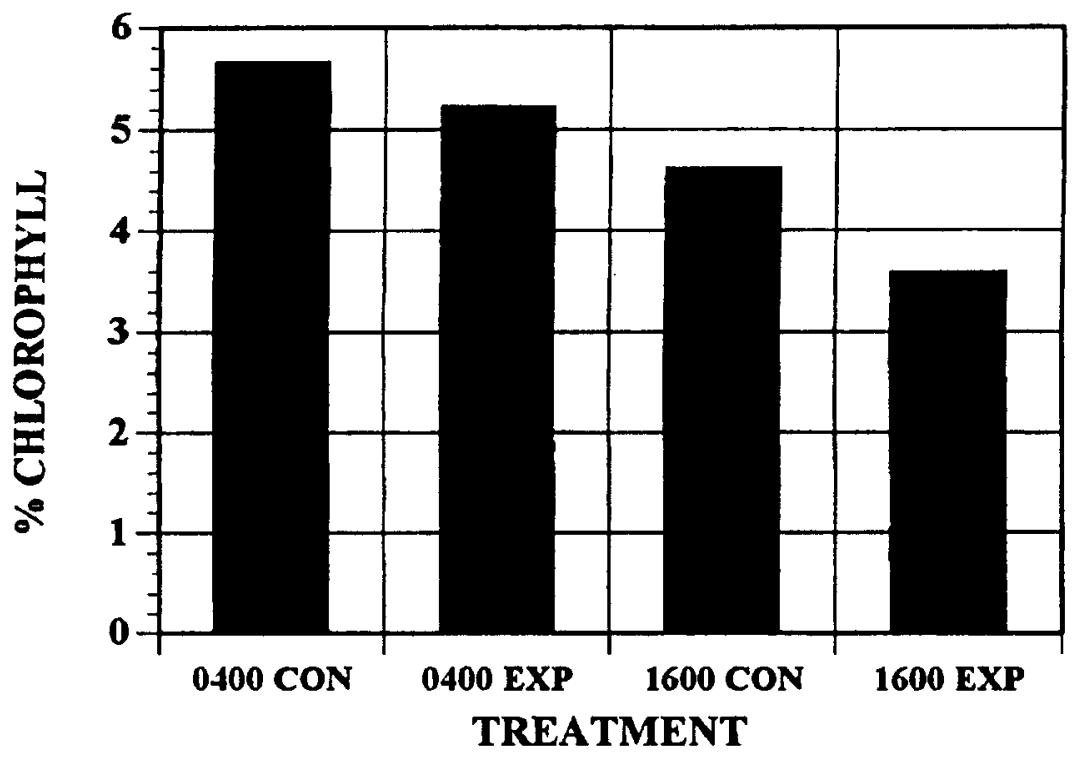

Fig. 11. Chlorophyll $a$ as a percent of TEL in control bottles and in 1,2,4trichlorobenzene treatments. $\mathrm{CON}=$ control; $\mathrm{EXP}=$ exposed.

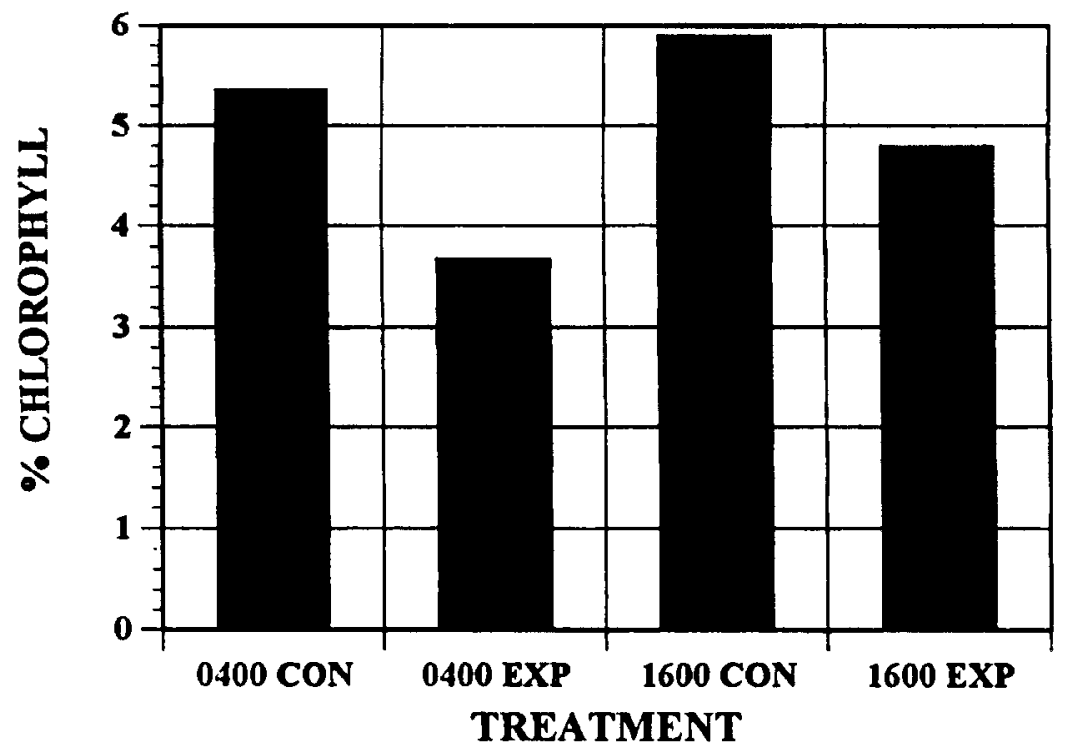

Fig. 12. Chlorophyll $a$ as a percent of TEL in control bottles and in 1,2,3 trichlorobenzene treatments. $\mathrm{CON}=$ control; EXP $=$ exposed. 
toxicant is initiated at different times of the day (Sicko-Goad and Andresen 1993a,b). The assemblages in this study were obtained from Lake Michigan in mid-July and were fairly typical offshore assemblages predominantly composed (greater than $90 \%$ of total cells) of diatoms. Even though we observed some reductions in dry weight and total cell counts in all trichlorobenzene exposures, it is difficult to say with certainty that the reductions were caused solely by the isomer. Although precautions were taken to screen out zooplankton by filtering the lake water, uneven distribution of smaller predators may have caused the observed changes in dry weight and assemblage composition. Reductions in cell numbers of diatoms as a result of exposure to trichlorobenzenes has been demonstrated (Sicko-Goad and Andresen 1993b). However, these reductions were observed 7-10 days after exposure, and it seems unlikely that in the short time frame of this experiment significant changes would be observed in diatom populations. Our visual technique does not resolve cytological changes which are reflected in the dry weight measurements. Phytoplankton analysis was conducted on cleared filters which present difficulties in differentiating between viable and dead cells.

What was obvious from the experiments was the alteration of lipid class composition by exposure to these isomers. The most obvious changes in lipid class composition were observed both in the neutral/polar lipid ratio and in the percentage of chlorophyll in the cells. For the assemblage, exposure to the chlorinated hydrocarbons resulted in an overall reduction in chlorophyll concentration and an increase in the neutral/polar lipid ratio. The magnitude of change was greater with exposure to 1,2,3-trichlorobenzene, which is not unexpected since 1,2,3-trichlorobenzene has 3 unsubstituted vicinal carbon positions and Williams et al. (1975) found that the extent of metabolism of chlorinated benzenes and potential epoxide formation depended on the number of unsubstituted vicinal carbon atoms. Galassi and Vighi (1981) also found that 1,2,3-trichlorobenzene was more toxic than the $1,2,4$ isomer in cultures of Selanastrum capricornutum.

The diel pattern of chlorophyll concentration in the assemblage shows that chlorophyll concentrations diminish after sunset and remain low throughout the night. At $0800 \mathrm{~h}$, approximately $2 \mathrm{~h}$ after sunrise, chlorophyll concentration reaches a maximum. Our culture experiments demonstrated that toxicant exposures initiated when cellular lipid profiles were characterized by periods of chlorophyll synthesis and lower neutral to polar lipid ratios resulted in more short-term or immediate effects (Sicko-Goad and Andresen 1993a,b). The present experiment corroborates these findings in that more overall effects were observed with toxicant exposures initiated at $0400 \mathrm{~h}$ than with exposures initiated at $1600 \mathrm{~h}$. The $0400 \mathrm{~h}$ assemblage was characterized by low chlorophyll concentration, followed by a substantial increase in chlorophyll at $0800 \mathrm{~h}$. Neutral to polar lipid ratios are approximately equal at 0400 and $1600 \mathrm{~h}$, suggesting that chlorophyll synthesis and the pattern of synthesis of total neutral and total polar lipids may be the key factors in determining relative toxicity.

We have utilized the chlorophyll $a$ to neutral lipid ratio and the neutral/polar lipid ratios as indicators of toxicity effects for several reasons. First and foremost, chlorophyll content very often decreases upon exposure to a wide variety of both organic and inorganic compounds (e.g. Sicko-Goad and Stoermer 1988). Second, neutral lipid content often increases as a result of nutrient stress or toxicant exposure (Fogg 1956, Sicko-Goad and Stoermer 1979, Shifrin and Chisholm 1981, Varum and Mykelstad 1984, Smith and Geider 1985, Millie, 1986; Sicko-Goad et al., 1986). Hence, a change in this ratio signals a response in one or two sensitive indicators of toxicant stress. 


\section{Conclusion}

Experiments in which natural phytoplankton assemblages were exposed to two isomers of TCB corroborated results of culture experiments demonstrated that the timing of the initial exposure to the toxicant may alter toxicity effects. An increase in immediate and/ or short-term effects is observed when diatoms are exposed to chlorinated benzenes during periods prior to the onset of a large increase in chlorophyll content, when the diatoms have especially high concentrations of polar lipids. The diel changes in lipid composition are sufficient to produce entirely different results in low-dose, short-term exposure experiments. We strongly suggest that comparative toxicity studies be initiated at the same time of day to avoid this effect.

\section{Acknowledgements}

Supported by grants $88-0315$ from the Air Force Office of Scientific Research and R-814194 from the Office of Exploratory Research, US Environmental Protection Agency. M. B. Edlund provided technical support. Contribution No. 561 of the Center for Great Lakes and Aquatic Sciences.

\section{References}

Abou-Waly, H., Abou-Setta, M.M., Nigg, H.N. and Mallory, L.L. (1991) Growth response of freshwater algae Anabaena flos-aquae and Selanastrum capricornutum to atrazine and hexazinone herbicides. Bull. Environ. Contam. Toxicol. 46, 223-9

Borgman, U. (1985) Predicting the effect of toxic substances on pelagic ecosystems. Sci. Tot. Environ. 44, 111-21.

Cairns, J. (1984) Are single species toxicity tests alone adequate for estimating environmental hazard? Environ. Monitor. Assess. 4, 259-73.

Fogg, G.E. (1956) Photosynthesis and formation of fats in a diatom. Ann. Bot. 20, 265-85.

Galassi, S. and Vighi, M. (1981) Testing toxicity of volatile substances with algae. Chemosphere 10, 1123-6.

Grimes, D.J. and Morrison, S.M. (1975) Bacterial bioconcentration of chlorinated hydrocarbon insecticides from aqueous systems. Microb. Ecol. 2, 43-59.

Jenkins, D.G. and Buikema, A.L., Jr. (1990) Response of a winter plankton food web to simazine. Envir. Toxicol. Chem. 9, 693-705.

Millie, D.F. (1986) Nutrient-limitation effects on the biochemical composition of Cyclotella meneghiniana (Bacillariophyta): an experimental and statistical analysis. Can. J. Bot. 64, $19-26$.

Nyholm, N. (1991) Toxic effects on algal phosphate uptake. Envir. Toxicol. Chem. 10, 581-4.

Orcutt, D.M. and Patterson, G.W. (1975) Sterol, fatty acid, and elemental composition of diatoms grown in chemically defined media. Comp. Biochem. Physiol. 50B, 579-83

Parrish, C.C. (1986) Dissolved and particulate lipid classes in the aquatic environment. Ph.D. thesis, Dalhousie University, Halifax, Nova Scotia, Canada, $259 \mathrm{pp}$.

Parrish, C.C. and Ackman, R.G. (1985) Calibration of the Iatroscan-Chromarod System for marine lipid class analysis. Lipids $20,521-30$.

Ruben, H.J., Cosper, E.M. and Wurster, C.F. (1990) Influence of light intensity and photoadaptation on the toxicity of PCB to a marine diatom. Envir. Toxicol. Chem. 9, 777-84.

Shifrin N.S. and Chisholm, S.W. (1981) Phytoplankton lipids: interspecific differences and effects of nitrate, silicate, and light-dark cycles. J. Phycol. 17, 374-84. 
Sicko-Goad, L. and Stoermer, E.F. (1979) A morphometric study of lead and copper effects on Diatoma tenue v. elongatum (Bacillariophyta). J. Phycol. 15, 316-21.

Sicko-Goad, L. and Stoermer, E.F. (1988) Effects of toxicants on phytoplankton with special reference to the Laurentian Great Lakes. In Evans, M.S., ed. Toxic Contaminants and Ecosystem Health: A Great Lakes Focus, pp. 19-51. New York. Wiley.

Sicko-Goad, L., Schelske, C.L. and Stoermer, E.F. (1984) Estimation of intracellular carbon and silica content of diatoms from natural assemblages using morphometric techniques. Limnol. Oceanogr. 29, 1170-8.

Sicko-Goad, L.M., Ladewski, B.G. and Lazinsky, D. (1986) Synergistic effects of nutrients and lead on the quantitative ultrastructure of Cyclotella (Bacillariophyceae). Arch. Envir. Contam. Toxicol. 16, 291-300.

Sicko-Goad, L., Evans, M.S., Lazinsky, D., Hall, J. and Simmons, M.S. (1989a) Effects of chlorinated benzenes on diatom fatty acid composition and quantitative morphology. IV. Pentachlorobenzene and comparison with trichlorobenzene isomers. Arch. Envir. Contam. Toxicol. 18, 656-68.

Sicko-Goad, L., Hall, J., Lazinsky, D. and Simmons, M.S. (1989b) Effects of chlorinated benzenes on diatom fatty acid composition and quantitative morphology. II. 1,3,5Trichlorobenzene. Arch. Envir. Contam. Toxicol. 18, 638-46.

Sicko-Goad, L., Hall, J., Lazinsky, D. and Simmons, M.S. (1989c) Effects of chlorinated benzenes on diatom fatty acid composition and quantitative morphology. III. 1,2,3-Trichlorobenzene. Arch. Envir. Contam. Toxicol. 18, 647-55.

Sicko-Goad, L., Lazinsky, D., Hall, J. and Simmons, M.S. (1989d) Effects of chlorinated benzenes on diatom fatty acid composition and quantitative morphology. I. 1,2,4Trichlorobenzene. Arch. Envir. Contam. Toxicol. 18, 629-37.

Sicko-Goad, L. and Andresen, N.A. (1993a) Effect of lipid composition on the toxicity of trichlorobenzene isomers to diatoms. I. Short-term effects of 1,3,5-trichlorobenzene. Arch. Envir. Contam. Toxicol. 24, 236-42.

Sicko-Goad, L. and Andresen, N.A. (1993b) Effect of diatom lipid composition on the toxicity of trichlorobenzene. II. Long-term effects of 1,3,5-trichlorobenzene. Arch. Envir. Contam. Toxicol. 24, 243-8.

Smets, B.F. and Rittmann, B.E. (1990) Sorption equilibria for trichloroethene on algae. Wat. Res. 24, 355-60.

Smith, R.E. and Geider, R.J. (1985) Kinetics of intracellular carbon allocation in a marine diatom. J. Exp. Mar. Biol. Ecol. 93, 191-210.

Varum, K.M. and Myklestad, S. (1984) Effects of light, salinity and nutrient limitation on the production of B-1, 3-D-Glucan and Exo-D-Glucanase activity in Skeletonema costatum (Grev.) Cleve. J. Exp. Mar. Biol. Ecol. 83, 13-25.

Williams, R.T., Hiron, P.C. and Renwick, A.G. (1975) Species variation in the metabolism of some organic halogen compounds. In A.D. McIntyre and C.F. Mills, eds, Ecological Toxicology Research, Effects of Heavy Metal and Organohalogen Compounds, pp. 91-106. New York Plenum Press. 